\title{
Cottonseed Yield and its Quality as Affected by Mineral Nutrients and Plant Growth Retardants
}

\author{
Zakaria M Sawan* \\ Cotton Research Institute Agricultural Research Center, Ministry of Agriculture and Land Reclamation, Egypt
} *Corresponding author: Zakaria M Sawan, Cotton Research Institute Agricultur-
al Research Center, Ministry of Agriculture and Land Reclamation, Egypt.
Received Date: April 19, 2021

Published Date: April 26, 2021

\begin{abstract}
Seed quality is one of the most important factors for stand establishment in cotton (Gossypium Sp.), and the use of good quality seeds is therefore essential to obtain an optimum plant population. Conditions prevailing during seed formation can affect the quality of seed produced, and hence crop establishment in the next growing season. These conditions can affect the germination of the seeds and the ability of the seedlings to emerge from soil, these being the most critical stages during the life cycle of cotton plant. Field experiments were conducted to investigate the effect of nitrogen $(\mathrm{N})$, phosphorus $(\mathrm{P})$, potassium $(\mathrm{K})$, foliar application of zinc (Zn) and calcium (Ca), the use of plant growth retardants (PGR's) [eg., 1, 1-dimethyl piperidinium chloride (MC); 2-chloroethyl trimethyl ammonium chloride (CC); or succinic acid 2, 2-dimethyl hydrazide (SADH)], during square initiation and boll setting stage, on growth, seed yield, seed viability, and seedling vigor of cotton [1]. Stand establishment of cotton seedlings is one of the most critical stages in cotton production. Cotton-seed quality is affected, to a large extent, by the indeterminate growth habit of the cotton plant, which allows seed to set and develop across an extended period of time. Seed vigor and viability are important components influencing seedling establishment, crop growth, and productivity. Any factor that negatively affects seed vigor and viability during seed development will have adverse consequences on crop production. Plant nutrition using a balanced fertilization programmer with both macro- and micro-nutrients has become very important in the production of high-quality seed. Plant growth retardants (PGR,s) represent diverse chemistries and mode of action, and provide numerous possibilities for altering crop growth and development, provide farmers with a new management tool for controlling undesirable vegetative growth, and to balance vegetative and reproductive growth as well as to improve yield and its quality [1].
\end{abstract}

Keywords: Phosphorus; Plant growth retardants; Potassium; Zinc

\section{Introduction}

Sowing is a critical time in the life cycle of any crop and the seeds are frequently exposed to adverse conditions that may compromise the establishment of seedlings in the field [2]. Stand establishment of cotton seedlings is one of the most critical stages in cotton production. Cotton-seed quality is affected, to a large extent, by the indeterminate growth habit of the cotton plant, which allows seed to set and develop across an extended period of time. Seed vigor and viability are important components influencing seedling establishment, crop growth, and productivity. Any factor (biotic and/or environmental) that negatively affects seed vigor and viability during seed development will have adverse consequences on crop production, especially when seeds are sown under environmentally stressful conditions [3]. Both size and number of seeds, produced by maternal plants, are most likely determined by their nutritional status at the time of flowering and bud initiation. Furthermore, the most important single determinant of mineral nutrient reserves in seeds is the mineral nutrient availability to the maternal plant during reproductive development, with increasing supplies of a particular mineral nutrient enhancing the nutrient concentration in the mature seed [4].

Plant nutrition using a balanced fertilization programmer with both macro- and micro-nutrients has become very important in the production of high-quality seed. Many management practices and breeding efforts have allowed plants to partition more 
carbohydrates into bowls and less into vegetative growth. Mineral nutritional status of plants has a considerable impact on partitioning of carbohydrates and dry matter between shoots and roots. Often, the number of sink organs is the yield component that is affected mostly by mineral nutrients. The positive effect of mineral nutrient supply on the number of sink organs may result not only from an increase in mineral nutrient supply, but also from an increase in photosynthate supply to the sink sites or from hormonal effects [5].

\section{Nitrogen (N)}

In cotton culture, $\mathrm{N}$ have the most necessity role in production inputs, which controls growth and prevents abscission of squares and bolls, essential for photosynthetic activity [6], and stimulates the mobilization and accumulation of metabolites in newly developed bolls, thus increasing their number and weight. Additionally, with a dynamic crop like cotton, excess $\mathrm{N}$ serves to delay maturity, promote vegetative tendencies, and usually results in lower yields [7]. Therefore, errors made in $\mathrm{N}$ management that can impact the crop can be through either deficiencies or excesses. With a dynamic crop like cotton, excess $\mathrm{N}$ serves to delay maturity, promote vegetative tendencies, and usually results in lower yields $[7,8]$. Therefore, errors made in $\mathrm{N}$ management that can impact the crop can be through either deficiencies or excesses. If an $\mathrm{N}$ deficiency is developing in a cotton crop, it is not particularly difficult to diagnose and correct. Excess $\mathrm{N}$ fertility levels, which, can be damaging to final crop productivity, are subtler to detect, and are difficult to correct [9].

\section{Phosphorus (P)}

Phosphorus $(\mathrm{P})$ is the second most limiting nutrient in cotton production after nitrogen Response to $\mathrm{P}$ fertilizer, however, is often difficult to predict, even with soil test-based applications [10]. The high soil $\mathrm{pH}(>7.6)$ and the high quantities of $\mathrm{CaCO} 3$ result in precipitation of $\mathrm{P}$, which reduces the soluble $\mathrm{P}$ supply. Its deficiency tends to limit the growth of cotton plants, especially when plants are deprived of phosphorus at early stages than later stages of growth [11]. P is also involved in cell division and development of meristematic tissues [12]. Moreover, on a whole-plant scale, $\mathrm{P}$ plays a decisive role in carbon assimilate transport and metabolic regulation [13]. Phosphorus deficiencies lead to a reduction in the rate of leaf expansion and photosynthesis per unit leaf area [14]. The high soil $\mathrm{pH}(>7.6)$ and the high quantities of $\mathrm{CaCO} 3$ result in precipitation of $\mathrm{P}$, which reduces the soluble $\mathrm{P}$ supply. Sasthri et al. [15] found that application of $2 \%$ diammonium phosphate to cotton plants increased seed yield, seed germination, root length, vigor index and dry matter production.

\section{Potassium (K)}

The physiological role of $\mathrm{K}$ during fruit formation and maturation periods is mainly expressed in carbohydrate metabolism and translocation of metabolites from leaves and other vegetative organs to developing bolls. $\mathrm{K}$ increases the photosynthetic rates of crop leaves, $\mathrm{CO} 2$ assimilation and facilitating carbon movement
[16]. At least sixty enzymes are known to be activated by this ion. The enzyme pyruvate kinas (more correctly referred to as ATP: pyruvate phosphotransferase), which participates in glycolysis [17]. The high concentration of $\mathrm{K}+$ is thought to be essential for normal protein synthesis. Potassium role in this process is considered to be the maintenance of a proper association between $t$ RNA molecules and ribosomes during the translation of mRNA [17]. Potassium also acts as an activator for several enzymes involved in carbohydrates metabolism. The requirement of cotton for $\mathrm{K}$ increases with the beginning of bud formation stage. A greater accumulation of sugars and starch in leaves under K-deficient conditions adversely affects development of bolls due to deficiency of metabolites. K deficiency during the reproductive period can limit the accumulation of crop biomass [18], markedly changes the structure of fruit-bearing organs, and decreases yield and quality. Pettigrew [19] stated that the elevated carbohydrate concentrations remaining in source tissue, such as leaves, appear to be part of the overall effect of $\mathrm{K}$ deficiency in reducing the amount of photosynthate available for reproductive sinks and thereby producing the changes in yield and quality seen in cotton.

\section{Calcium (Ca)}

Ca is essential in cell nucleus matrix. It activates enzymes, particularly those that are membrane-bound [20]. Calcium is important in membrane permeability, maintenance of cell integrity, and in ion uptake. Calcium deficiency may also decrease the basipetal transport of auxin [21]. Addicot and Lyon [22] listed Ca deficiency as one of the causes of abscission and suggested this plus the role of $\mathrm{Ca}$ in the middle lamella (Ca pectates) as the possible reason. It is thought that $\mathrm{Ca}$ is important in the formation of cell membranes and lipid structures. Ma and Sun [23], suggested that Ca might be involved in light signal transduction chain for phototropism. Ca also plays an important role in plant growth as a major component of the middle lamella (calcium pectate). A likely reason was that Ca deficiency affected translocation of carbohydrates, causing accumulation in the leaves and a decline in stems and roots.

\section{Zinc (Zn)}

Although only small amounts of Zn are removed from the field by a cotton crop ( 0.5 ounces per bale), $\mathrm{Zn}$ is critical for several key enzymes in the plant [24]. Zinc influences electron transfer reactions, including those of the Kreb cycle, and thereby affecting the plant's energy production. Zinc binds tightly to Zn-containing essential metabolites in vegetative tissues, eg, Zn-activated enzymes such as carbonic anhydrase [3]. Zn deficiency has been shown to affect growing sink organs; it adversely affects the development and viability of pollen grains [25]. Zinc deficiency occurs on highpH soils, particularly where topsoil has been removed in preparing fields for irrigation and thereby exposing the Zn-deficient subsoil. Also, Zn deficiencies have occurred where high rates of $\mathrm{P}$ are applied. The high $\mathrm{P}$ rates in the plant interfere with the utilization of $\mathrm{Zn}[26]$. 


\section{Plant growth retardants (PGR's)}

PGR represent diverse chemistries and mode of action and provide numerous possibilities for altering crop growth and development [27]. PGR's [eg, 1, 1-dimethyl piperidinium chloride (MC); 2-chloroethyl trimethyl ammonium chloride (CC); or succinic acid 2, 2-dimethyl hydrazide (SADH)]. provide farmers with a new management tool for controlling undesirable vegetative growth An objective for using PGR in cotton is to balance vegetative and reproductive growth as well as to improve yield and its quality [28]. Visual growth-regulating activity of MC, CC or SADH is similar $[29,30]$, being expressed as reduced plant height and width (shortened stem and branch internodes and leaf petioles), influence leaf chlorophyll concentration, structure and $\mathrm{CO} 2$ assimilation, and thicker leaves.

In Egypt, soil fertilization is the primary limiting factor affecting growth and production under intensive land use for two or more crops per year. Furthermore, recently released varieties have high yielding ability, which largely depends on ensuring the plant's essential nutritional requirements (eg, N, P, K, Ca; Zn). Considerable interest also exists in using PGR for cotton production because of their potential for altering crop growth and seed development [27]. All environmental factors and their interactions that influence plant growth can potentially influence the complicated and dynamic processes that control their seed initiation, development, and seed nutrient reserves. These factors can modify the ultimate vigor and viability of seeds [31]. The objectives of this study were to evaluate the effects of $\mathrm{N}$ and $\mathrm{P}$, and $\mathrm{K}$ fertilization and foliar application of chelated $\mathrm{Ca}$ and Zn nutrients, and the PGR's (eg, MC, CC or SADH) during square initiation and boll setting stage and to identify the best combination of these production treatments in order to improve seed yield, seed weight, and seed quality (as measured by seed viability, seedling vigor and cool germination test) of Egyptian cotton (G. barbadense).

\section{Conclusion}

From the findings of this study, it seems rational to recommended application of $\mathrm{N}$ at a rate of $161 \mathrm{of} \mathrm{kg}$ ha- 1 , spraying of cotton plants with plant PGR, and application of $\mathrm{Zn}$ in comparison with the ordinary cultural practices adopted by Egyptian cotton producers, it is quite apparent that applications of such PGR, Zn, and increased $\mathrm{N}$ fertilization rates could bring about better impact on seed yield and seedling characters studied [32].

Under the conditions of this study, it can be concluded that addition of P at $74 \mathrm{~kg}$ ha-1 P2O5 and spraying cotton plants with $\mathrm{Zn}$ at $40 \mathrm{ppm}$ and also with Ca at $60 \mathrm{ppm}$ can be recommended to improve cotton seed yield, viability, and seedling vigor [33].

Application of $\mathrm{N}$ at the rate of $142.8 \mathrm{~kg}$ ha- 1 and application of $\mathrm{K}$ (foliar, at the rate of $1.15 \mathrm{~kg}$ ha- $1 \mathrm{~K} 20$ ) and $\mathrm{MC}$ (at the rate of $0.048+0.024 \mathrm{~kg}$ ha-1 MC) should help achieve higher cotton seed productivity and quality (seed viability and seedling vigor) in comparison with the usual cultural practices adopted by Egyptian cotton procedures [34]. From the findings of this study, the addition of $\mathrm{K}$ at $47 \mathrm{~kg}$ ha-1, spraying cotton plants with Zn twice (at $57 \mathrm{~g}$ ha1), and also with P twice (especially the P concentration of $1728 \mathrm{~g}$ ha-1) along with the soil fertilization used $\mathrm{P}$ at sowing time have been proven beneficial to the quality and yield of cotton plants. These combinations appeared to be the most effective treatments, affecting cottonseed productivity and quality (as indicated by better seed viability, seedling vigor, and cool germination test performance) [31]. In comparison with the ordinary cultural practices adopted by Egyptian cotton producers, it is apparent that the applications of such treatments could produce an improvement in cottonseed yield and quality.

\section{Acknowledgement}

None.

\section{Conflict of Interest}

No conflict of interest.

\section{References}

1. Sawan ZM (2017) Cottonseed yield and its quality as affected by mineral nutrients and plant growth retardants. Cogent Biology, 2: 1245938.

2. Albuquerque MC de Fe, de Carvalho NM (2003) Effect of the type of environmental stress on the emergence of sunflower (Helianthus annuus L), soybean (Glycine max (L) Merril) and maize (Zea mays L) seeds with different levels of vigor. Seed Science and Technology 31: 465-479.

3. Welch RM (1995) Micronutrient nutrition of plants. CRC Critical Reviews in Plant Science 14: 49-82.

4. Fenner M (1992) Environmental influences on seed size and composition. Horticultural Reviews 13: 183-213.

5. Borowski E (2001) The effect of nitrogenous compounds on the growth, photosynthesis and phosphorus uptake of sunflowers. Annales Universitatis Mariae Curie-Sklodowska. Sectio EEE, Horticultura 9: 2331.

6. Reddy AR, Reddy KR, Padjung R, Hodges HF (1996) Nitrogen nutrition and photosynthesis in leaves of Pima cotton. Journal of Plant Nutrition 19: 755-770.

7. Rinehardt JM, Edmisten KL, Wells R, Faircloth JC (2004) Response of ultra-narrow and conventional spaced cotton to variable nitrogen rates. Journal of Plant Nutrition 27: 743-755.

8. McConnell JS, Baker WH, Frizzell BS (1996) Distribution of residual nitrate- $\mathrm{N}$ in longterm fertilization studies of an alfisol cropped for cotton. Journal of Environmental Quality 25: 1389-1394.

9. Silvertooth JC, Norton ER (1998) Evaluation of a feedback approach to nitrogen and Pix application, 1997. Cotton, A College of Agriculture Report. Series P-112, University of Arizona, Tucson, AZ, pp. 469-475.

10. Bronson KF, Onken AB, Keeling JW, Booker JD, Torbert HA (2001) Nitrogen response in cotton as affected by tillage system and irrigation level. Soil Sci Soc America J 65: 1153-1163.

11. Hearn AB (1981) Cotton nutrition. Field Crop Abst 34: 11-34.

12. Russell EW (1973) Soil Condition and Plant Growth. The English Language Book Society and Longman, London pp. 448

13. Bisson P, Cretenet M, Jallas E (1994) Nitrogen, phosphorus and potassium availability in the soil-physiology of the assimilation and use of these nutrients by the plant. Challenging the Future: In Proceedings of the World Cotton Research Conference-1, Brisbane Australia, February 14-17, G A Constable and NW Forrester (eds), CSIRO, Melbourne, pp. $115-124$ 
14. Rodriguez D, Zubillaga MM, Ploschuck E, Keltjens W, Goudriaan J, et al. (1998) Leaf area expansion and assimilate prediction in sunflower growing under low phosphorus conditions. Plant Soil 202: 133-147.

15. Sasthri G, Thiagarajan CP, Srimathi P, Malarkodi K, Venkatasalam EP (2001) Foliar application of nutrient on the seed yield and quality characters of nonaged and aged seeds of cotton cv. MCU5. Madras Agricultural Journal 87: 202-206.

16. Sangakkara UR, Frehner M, Nösberger J (2000) Effect of soil moisture and potassium fertilizer on shoot water potential, photosynthesis and partitioning of carbon in mungbean and cowpea. Journal of Agronomy and Crop Science 185: 201-207.

17. Glass ADM (1989) Plant Nutrition. An Introduction to Current Concepts Jones and Bartlett Publishers. Boston/Portola Valley, USA: Jones and Bartlett Publishers.

18. Colomb B, Bouniols A, Delpech C (1995) Effect of various phosphorus availabilities on radiation-use efficiency in sunflower biomass until anthesis. Journal of Plant Nutrition 18: 1649-1658.

19. Pettigrew WT (1999) Potassium deficiency increases specific leaf weights of leaf glucose levels in field-grown cotton. Agronomy Journal 91: $962-968$

20. Rensing L, Cornelius G (1980) Biological membranes as components of oscillating systems. Biologische Rundschau 18: 197-209.

21. De la Fuente RK, Leopold AC (1973) A role for calcium in auxin transport Plant Physiology 51: 845-847.

22. Addicott FT, Lyon JL (1973) Physiological ecology of abscission. In Shedding of Plant Parts, (ed. TT Kozlowski), Academic Press, New York and London, pp. 85-123.

23. Ma LG, Sun DY (1997) The involvement of calcium in the light signa transduction chain for phototropism in sunflower seedling. Biologia Plantarum 39: 569-574.

24. Sharma CP, Sharma PN, Bisht SS, Nautiyal BD (1982) Zinc deficiency induced changes in cabbage. In: A. Scaife (ed.). Proceeding of the $9^{\text {th }}$ Plant Nutrition Colloquy, Warwick, England. 22-27 Aug. Commonwealth Agric. Bur. Farnham House, Slough, England, Pp. 601-606
25. Sharma PN, Chatterjee C, Agarwala SC, Sharma CP (1990) Zinc deficiency and pollen fertility in maize (Zea mays). Plant and Soil 124: 221-225.

26. Oosterhuis D, Hake K, Burmester C (1991) Leaf feeding insects and mites. Cotton Physiology Today, July Cotton Council of America 2(8): 1-7.

27. Cothren JT (1994) Use of growth regulators in cotton production Challenging the Future: In Proceedings of the World Cotton Research Conference-1, Brisbane Australia, February 14-17, Constable GA, Forrester NW (eds), CSIRO, Melbourne, pp. 6-24

28. Zhao DL, Oosterhuis DM (2000) Pix Plus and mepiquat chloride effects on physiology, growth, and yield of field-grown cotton. Journal of Plant Growth Regulation 19: 415-422.

29. Heyendorff Scheel RC von, Schott PE, Rittig FR (1983) mepiquat chloride, a plant growth regulator for cotton. Zeitschrift fur Pflanzenkrankheiten und Pflanzenschutz 90: 585-590.

30. Stuart BL, Isbell VR, Wendt CW, Abernathy JR (1984) Modification of cotton water relations and growth with mepiquat chloride. Agronomy Journal 76: 651-655.

31. Sawan ZM, Fahmy AH, Yousef SE (2011) Effect of potassium, zinc and phosphorus on seed yield, seed viability and seedling vigor of cotton (Gossypium barbadense L.). Archives of Agronomy and Soil Science 57: $75-90$

32. Sawan ZM, Gregg BR, Yousef SE (1998) Influence of nitrogen fertilisation and foliar-applied plant growth retardants and zinc on cotton seed yield, viability and seedling vigour. Seed Science and Technology 26: 393-404.

33. Sawan ZM, Gregg BR, Yousef SE (1999) Effect of phosphorus, chelated zinc and calcium on cotton seed yield, viability and seedling vigour. Seed Science and Technology 27: 329-337.

34. Sawan ZM, Fahmy AH, Yousef SE (2009) Direct and residual effects of nitrogen fertilization, foliar application of potassium and plant growth retardant on Egyptian cotton growth, seed yield, seed viability and seedling vigor. Acta Ecologica Sinica 29: 116-123. 